\title{
Forests and Landscapes of Dominican Republic
}

\author{
Ana Cano-Ortiz ${ }^{1}$, Carmelo Maria Musarella ${ }^{2}$, José Carlos Piñar Fuentes ${ }^{3}$, \\ Carlos Jose Pinto Gomes ${ }^{4}$ and Eusebio Cano ${ }^{3^{3}}$ \\ ${ }^{1}$ Department of Sustainability Interra, Engineering and Resources SL, Plaza España, 317, \\ 5.C.P.27004, Salamanca, Spain. \\ ${ }^{2}$ Department of AGRARIA, University Mediterranea of Reggio Calabria, Feo di Vito, 89122 Reggio \\ Calabria, Italy. \\ ${ }^{3}$ Department of Animal and Plant Biology and Ecology, Section of Botany, University of Jaén, Campus \\ Universitario Las Lagunillas s/n. 23071 Jaén, Spain. \\ ${ }^{4}$ Department of Landscape, Environment and Planning / Institute of Agricultural and Environmental \\ Sciences Mediterranean (ICAAM), University of Evora, Portugal.
}

\section{Authors' contributions}

This work was carried out in collaboration between all authors. Author AC-O designed the study, performed the statistical analysis, wrote the protocol and wrote the first draft of the manuscript and managed literature searches. Authors CMM, JCPF, CJPG and EC managed the analyses of the study and literature searches. All authors read and approved the final manuscript.

Article Information

DOI: 10.9734/BJAST/2015/17507 Editor(s):

\section{ABSTRACT}

Aims: This, in conjunction with the diversity of the substrates and the fact that the island is home to the highest mountains in the Caribbean and with a high rate of endemic species, allows them to be differentiated into three major groups -dry forest, cloud forest and the transition between dry and cloud forests. The forests in the Dominican Republic grow in a tropical climate with ombrotypes ranging from arid to humid-hyperhumid due to the moisture-laden Atlantic winds; and infra-, thermo-, meso- and supratropical thermotypes. Establish the diversity, ecology and forest types in Dominican Republic.

Methods: We identified all species through field surveys and comparative analyzes of how forest types, structure, diversity and ecology. 
Results: We consided these forests to be endemic to the island of Hispaniola, as the dry forest presents 81 endemic species, of which 10 are trees, 65 shrubs, 5 creepers, and 1 herbaceous species; while the cloud forest has 19 trees, 20 shrubs, 8 creepers, 4 epiphytes and 6 herbaceous species.

Conclusions: We highlight the absence of endemic epiphytes in the dry forests, which are in a poor state of conservation and subject to greater human pressure than the cloud forest.

Keywords: Forests; diversity; endemics; structure; deterioration; conservation.

\section{INTRODUCTION}

Some works on vegetation published in the local journal of the Santo Domingo Botanical Garden (Moscosoa) have been of assistance in this research. The influence of the rains on the forest distribution in the Dominican Republic is similar to that of south and southwest China [1]; these forests have a similar diversity and structure to those in the north of the island of Okinawa (Japan) [2] and their distribution is conditioned by climate models and human intervention. Deforestation at the hands of the local population, essentially in arid and semiarid zones, has led to the deterioration of these forests in the Dominican Republic and Haiti, similar to the situation in Ethiopia [3]. As a result the emergence of secondary plant communities with a similar structure to those found in subtropical areas of China [4]; however when deforestation occurs in the cloud forest, it gives rise to a "calimetal or fern community" of Gleichenia bifida (Willd.) Spreng. and Dicranopteris flexuosa (Schrad.) Underw., whose vigorous growth and dense coverage hinder the regeneration of the forest. The deforestation of broadleaf and mixed forest is carried out by livestock and agricultural farmers and the repercussion of fire varies depends on the environmental conditions and the type of forest [5-9]. In cases where the broadleaf (cloud) forest is burned, its dense coverage prevents the regeneration of the primary forest. We do not therefore agree with [10] that the spatial structure of the forest should be changed by frequent burning. However, if we agree with [11] as the disturbances produced by fire in the cloud forest, causing changes in the composition and structure of the forest, which for fire resistant species is replaced, such as example the species of "calimetal".

The deterioration of the forests on the island of Hispaniola is exacerbated by the Caribbean hurricanes, which have a serious impact on their structure [12]. However, the mountains on the island are still home to a number of well- conserved areas thanks to a close linear correlation between environmental factors and forest types. In the case of well-conserved autochthonous forests and areas with secondary forests due to clearing by farmers [13], secondary forests may be better adapted to climate change than primary forests, making management of these forests fundamental to mitigating this climate change $[14,15]$. Therefore, there is an urgent need to enact legislative policies as has occurred in neighbouring countries such as Brazil, Costa Rica, and Guatemala [16].

\section{METHODS 21}

A study was made of the areas of dry, cloud and the transition between both forests in the Dominican Republic (Hispaniola) (Fig. 1). Ecologically and physiognomically homogeneous plots were selected and the species they contained were noted using [17]. The bioclimatic and biogeographical study was based on previous works $[18,19]$. To obtain the hierarchical cluster, we used the dissimilarity with Euclidean distance and Ward's agglomeration. Statistical analysis is generated automatically by the software XLSTAT and PCA with Spearman correlation. To separate the two major vegetation units (cloud forest and dry forest), we rely on the floristic composition of species Magnolia hamorii Howard (Maha), Sideroxylon salicifolium (L.) Sw. (Sisa), Metopium toxiferum (L.) Krug. \& Urb. (Meto) and Sideroxylon foetidissimum Jacq. (Sifo), all species characteristic of the transitional subhumid forest between dry and cloud forest; and a canonical correspondence analysis (CCA) between the lo (ombrothermic index), ETP (potential evapotranspiration), It/Itc (Thermicity index) and Ic (Continentality index) of the 65 plots in the sample and the dominant species, located at altitudes below 1,200 m: Bursera simaruba (L.) Sarg. (Busi), Metopium toxiferum (Meto), Pilosocereus polygonus (Lam.) B. \& R. (Pipo), Sideroxylon foetidissimum (Sifo), Sideroxylon salicifolium (Sisa), Didymopanax tremulus Krug. \& Urb. (Ditr), Hyeronima 
domingensis Urb.(Hydo), Magnolia hamorii (Maha), Magnolia pallescens Urb. \& Ekm.(Mapa), Prestoea montana (Grah.) Nichol.(Prmo) and Pinus caribaea Morelet. This last species forms mixed stands with the cloud forest and gives the name to the vegetation class Byrsonimo-Pinetea caribaea Samek and Borhidi in Borhidi et al. 1979; this tropical plant acts as an exotic outside its distribution area (Central America), and is a well adapted species in other tropical areas such as southern China [20].

\section{RESULTS AND DISCUSSION}

The CCA (Fig. 2) shows two groups of inventories: -R1-R39, representing the dry forest and dominated by Bursera simaruba, Metopium toxiferum (L.) Krug. \& Urb., Pilosocereus polygonus (Lam.) B. \& R., Sideroxylon foetidissimum Jacq., Sideroxylon salicifolium (L.) Sw., Prosopis juliflora L., Lemairocereus hystrix Britt \& Rose and Acacia macracantha H. \& B. Ex Willd; and the group C40-C65 dominated by Didymopanax tremulus Krug. \& Urb., Hyeronima domingensis Urb., Magnolia hamorii Howard, Magnolia pallescens Urb. \& Ekm., Prestoea montana (Grah.) Nichol., Alchornea latifolia Sw.,
Cyathea arborea (L.) J.E. Smith and Cyathea furfuracea Baker.

The PCA analysis of 28 dominant species produces two groups: $A$ (cloud forest) and $B(C$ subhumid forest, and $D$ dry forest) (Fig. 3). The two groups $A$ and $C$ in the PCA are maintained in the cluster. The first group (A) represents the cloud forest dominated by Magnolia hamorii Howard, Magnolia pallescens Urb. \& Ekm, Prestoea montana (Grab.) Nichol, Didymopanax tremulus Krug \& Urb., Alchornea latifolia Sw., Cyathea furfuracea Baker, Ormosia krugii Urb., Cyathea arborea (L.) E. Smith. This forest is well represented in the central and northern mountain ranges, the Sierra de Bahoruco and the eastern range. It is characterised by a high floristic diversity and a high rate of endemics. Recently in [21] we reported that this type of forest has $23 \%$ tree species, $16.6 \%$ climbers and $21.7 \%$ epiphytes, with 45 endemic species characteristic of the cloud forest in the Los Haitises National Park. Current studies show that this type of forest has a high rate of exclusive endemic plants (northern cordillera: 44; eastern cordillera: 13; central cordillera: 278; and Bahoruco: 482 species).

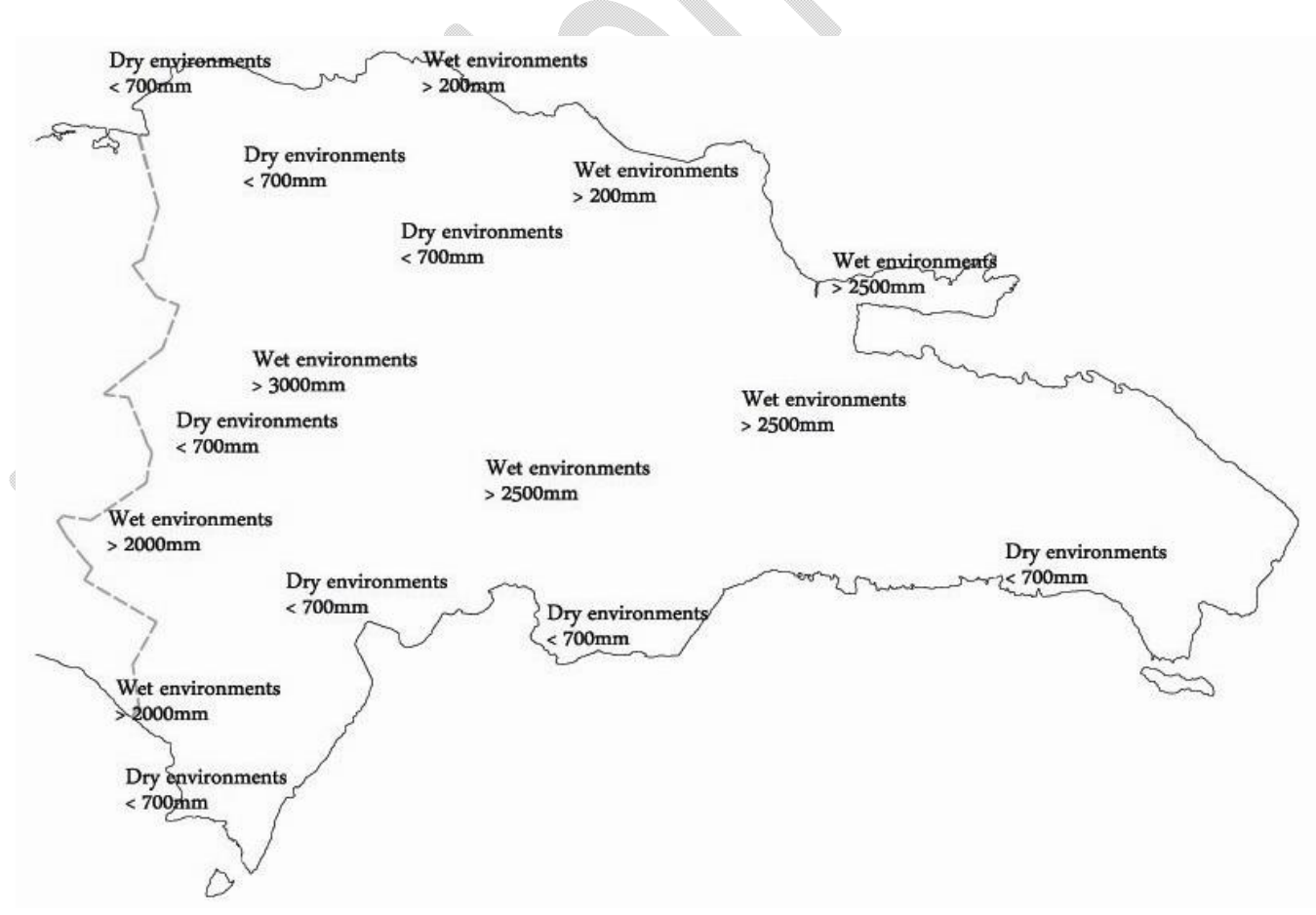

Fig. 1. Environments of the study area 
In the analysis of the diversity of the two forests types (dry and rain); in the dry forest there are 61 species of tree and 5 stipes, of which 10 are endemic, compared to 75 in the cloud forest and 4 stipes, of which 19 are endemic, being greater the number of epiphytic in cloud forest in the dry, with 36 species compared to 13 (Table 1). Shannom index gives values of 3,384 and 3,528 for the dry forest and cloudy respctively (Figs. 4,5,6).

The second group $B$ constituted by the $R$ inventories has little affinity group A consists of two subgroups $C$ and $D$ have a greater affinity between the two (Fig. 7).

Group C represents the subhumid transitional forest. The greater affinity with the forest is due to the presence of the species Pilosocereus polygonus (Lam) B. \& R., Lemairocereus hystyrix
Britt., and Leptocereus weingartianus (Hartm.) Britt. \& Rose, due to the fact that the substrates are coralline limestone with high infiltration. Recently [22,23] highlighted two types of subhumid forest in the eastern plains of the Dominican Republic with 30 endemic species and a coverage that ranges between $90-100 \%$.

Group $D$ represents the dry forest, dominated by species from the genera Prosopis, Lemairocereus, Pilosocereus, Cylindropuntia, Agave and Bursera. This type of forest is prevalent in the areas of Azua, Bani, San Juan, Enriquillo, Pedernales, Montecristi and the Cibao Valley. As a result of the presence of a specific local flora, there are a variety of subgroups, with a low discrimination at the cluster level at which are very valuable due to their high rate of exclusive endemics.

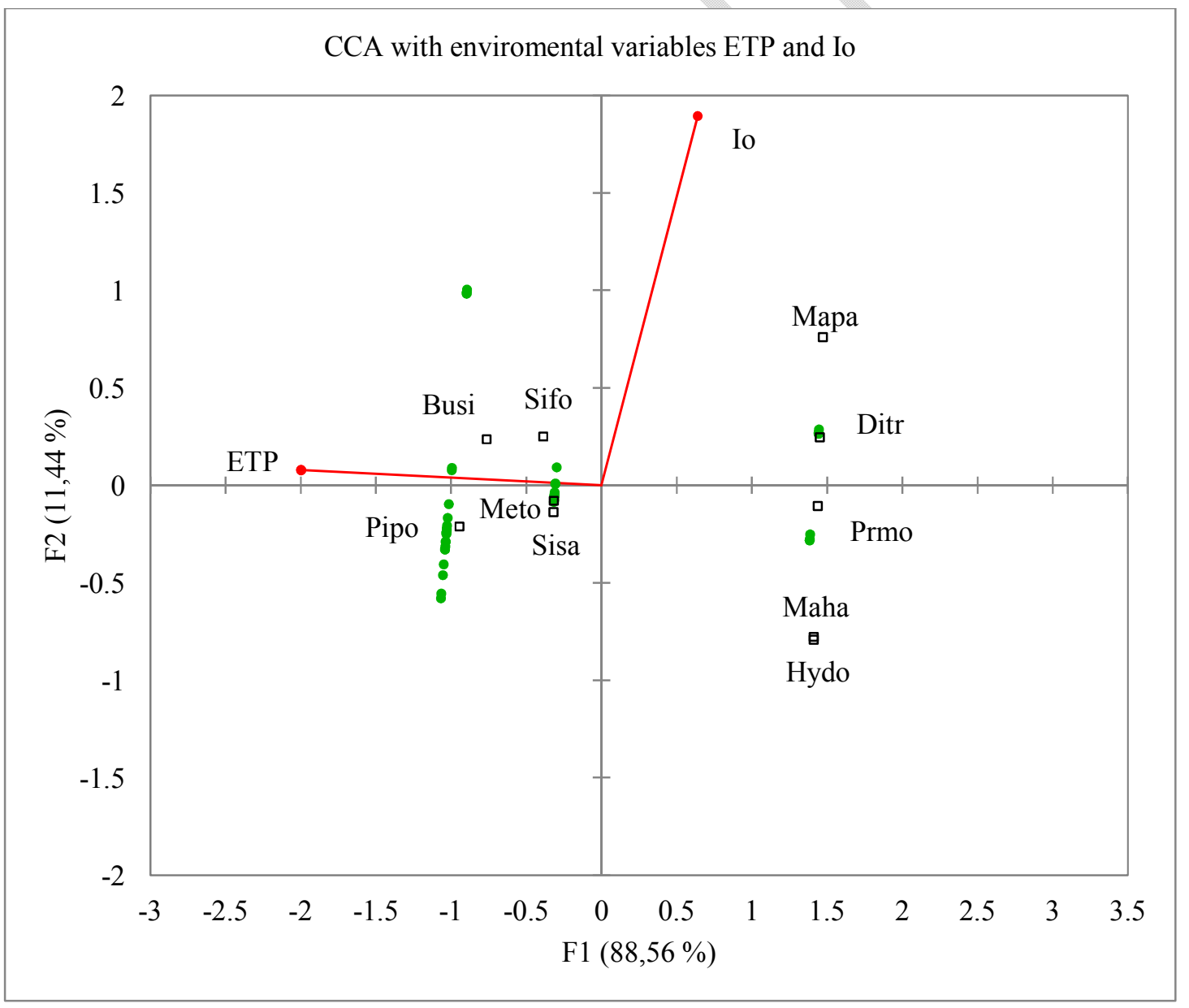

Fig. 2. Canonical correspondence analysis (CCA) 
Cano-Ortiz et al.; BJAST, 9(3): xxx-xxx, 2015; Article no.BJAST.2015.263

PCA Plot - Correlation - DIVERSITY_FOREST_PLANTS

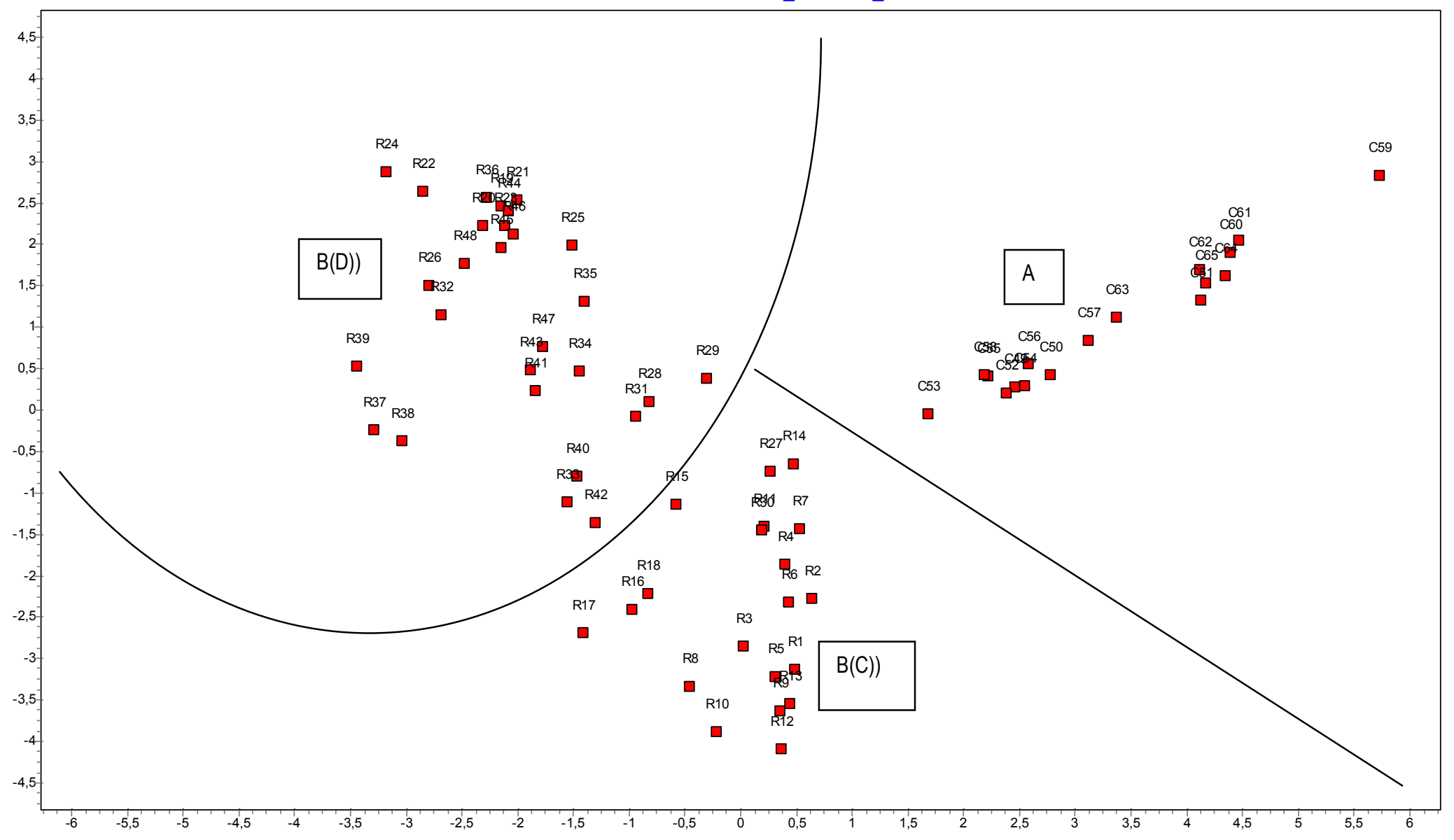

Fig. 3. Principal components analysis (PCA) for cloud (A) and $B$ (C subhumid and $D$ dry forest) 
Table 1. Species diversity in the dry and cloudy forests Dominican Republic

\begin{tabular}{|c|c|c|c|c|c|c|c|c|}
\hline & Trees & Stipes & Shrubbery & Succulents & Climber & Epiphytes & Herbaceous & 5. species \\
\hline Dry ff & 61 & 5 & 158 & 16 & 44 & 13 & 28 & 322 \\
\hline Rain & 75 & 4 & 63 & 0 & 28 & 36 & 43 & 244 \\
\hline
\end{tabular}

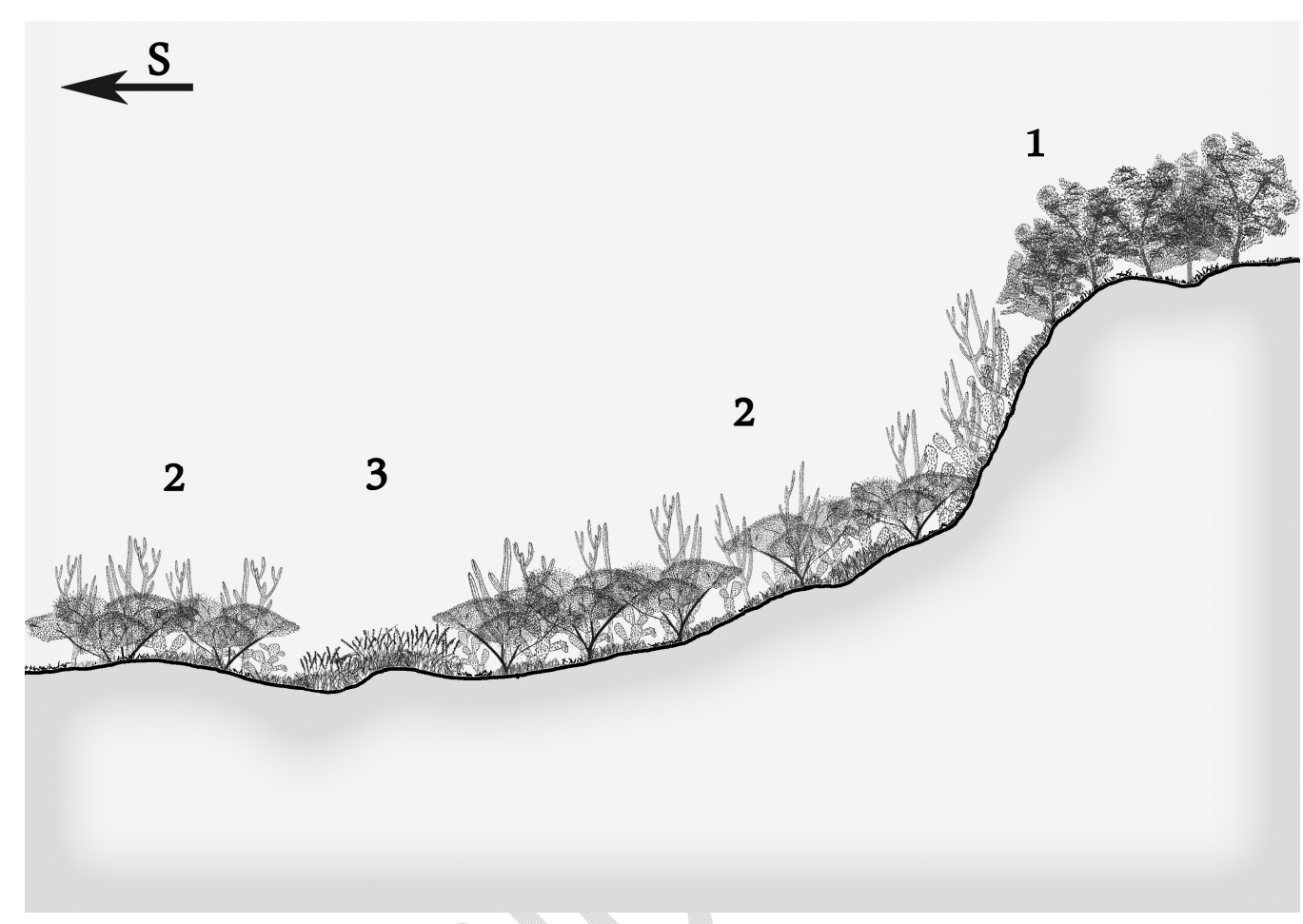

Fig. 4.- Profile of the vegetation of the cloud forest of Sierra Bahoruco. 1.- Rhabdadenio bifloriLaguncularietum racemosae and Lonchocarpo pycnophylli-Conocarpetum erecti. 2.- Salt marshes of Batidi-Salicornietea. 3.- Lonchocarpo pycnophylli-Cylindropundietum caribaeae. 4.- Melocacto pedernalensis-Leptochloopsietum virgatae. 5.- Broad-leaved forest. 6.- Cloud forest of Prestoea montana

One subgroup includes the inventories taken in the Cibao Valley (Montecristi), in infratropical environments with a semiarid ombrotype on quaternary loans, with 17 endemic species, Karwinskia coloneura Urb. and Justicia abeggii Urb. \& Ekm., exclusive to the territory. The subgroup is dominated by Prosopis juliflora L., Lemairocereus hystrix Britt. \& Rose, Harrisia nashii Britt. \& Rose, Consolea moniliformis (L.) Hawoth in Steud and Pilosocereus polygonus (Lam.) B. \& R.

This subgroup is a community that grows in the outlying areas of the Cibao Valley in the infra and dry thermotropical thermotype. This is an intricate forest dominated by Erythroxylum rotundifolium Lunan and Maytenus buxifolia (A. Rich.) Griseb., with 36 endemic plants, of which the following are exclusive to the territory: Lantana leonardorum Moldenke, Lantana pauciflora Urb., Croton gonaivensis Urb. \& Ekm., Lantana buchii Urb., Guettarda tortuensis Urb. \& Ekm. and Galactia synandra Urb. (Fig. 8).

The areas of Ázua, Bani, San Juan, Enriquillo and Port au Prince (Haiti) have a dry infratropical thermotype and are home to a spinescent forest growing on Miocene loams. In this forest there is a predominance of Guaiacum officinale L., Capparis cynophallophara L., Bourreria divaricata (DC.) G. Don and Cylindropuntia caribaea (Britt. \& Rose) Kunth; and 16 endemic plants, including particularly Coccotrinax spissa Bailey and Neoabbottia paniculata (Lam.) Britt. \& Rose (Fig. 9). 


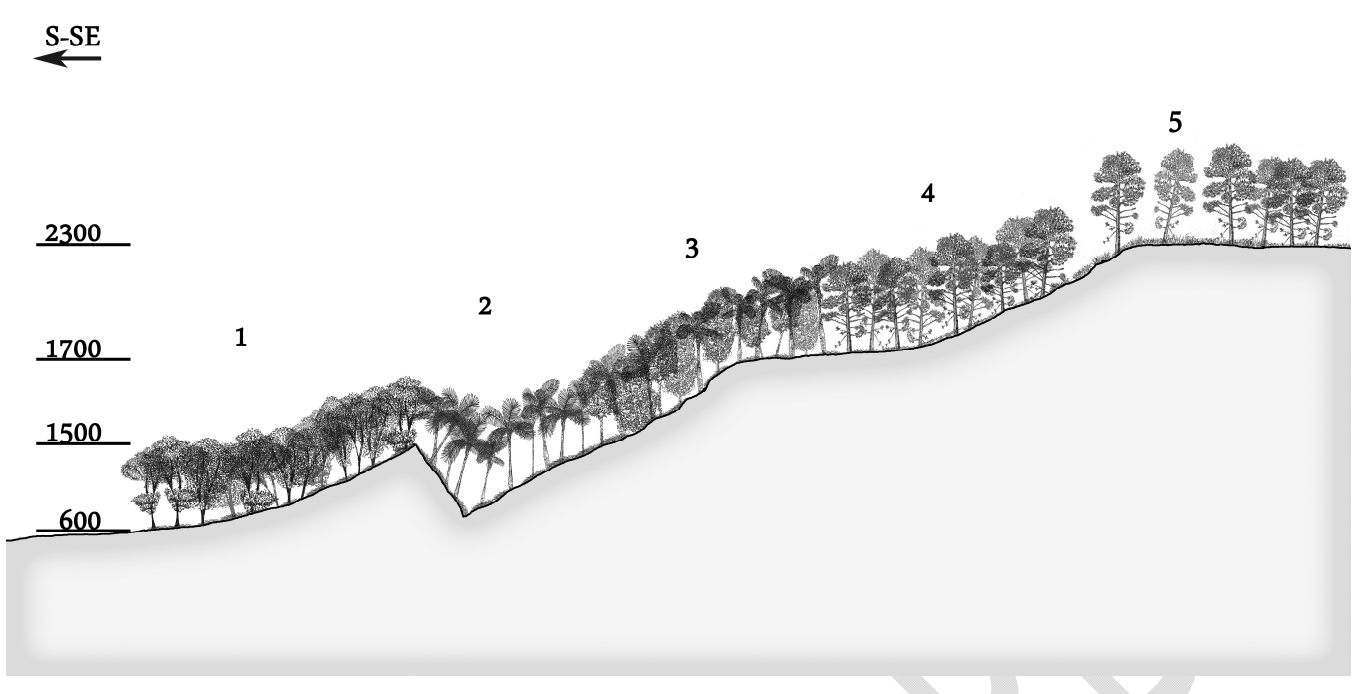

Fig. 5. Profile of the vegetation of the central range. 1.- Subhumid latifoliate forest. 2."Manacla" plantation of Cyathea furfuracea and Prestoea montana. 3.- Community of Palo de Viento Didymopanax and Magnolia pallescens with isolated elements of Prestoea montana. 4.Pine forest of Pinus occidentalis belonging to the community of Dendropemon phycnophyllus Krug an urb. and Pinus occidentalis Sw. 5.- Hemicryptophytic high-mountain grassland of Danthonia domingensis between the cleared pine forests of Pinus occidentalis

3

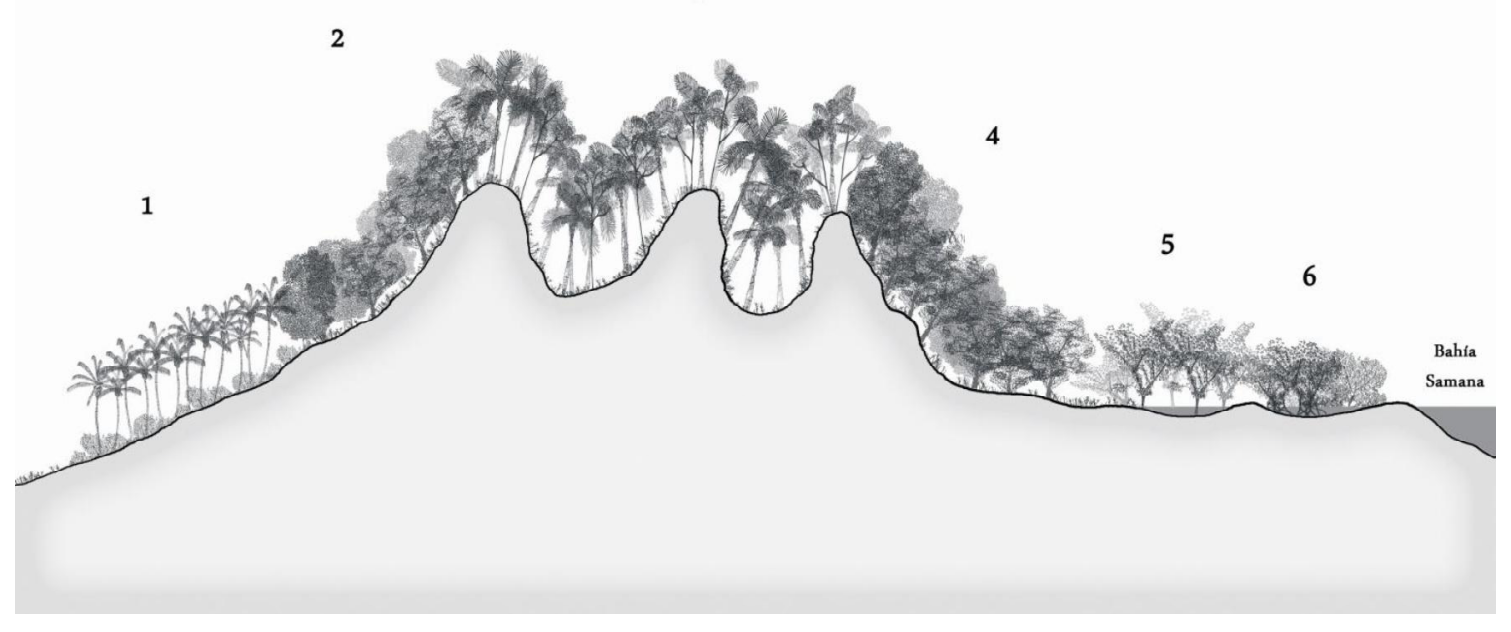

Fig. 6. Profile of the vegetation of the Haitises (A6).- 1.- Coconut crops. 2.- Latifoliate mahogany forest Swietenia mahagoni. 3.- Ormosia krugii and Prestoea Montana which is enriched on the summits witt Didymopanax morotononi. 4.- Latifoliate mahogany forest of

Swietenia mahagoni similar to 2. 5.- Community Roystonea hispaniolana Bailey and

Pterocarpus officinalis Jacq. 6.- Community Machaerium lunatum (L.f.) Ducke and Rhyzophora mangle L 


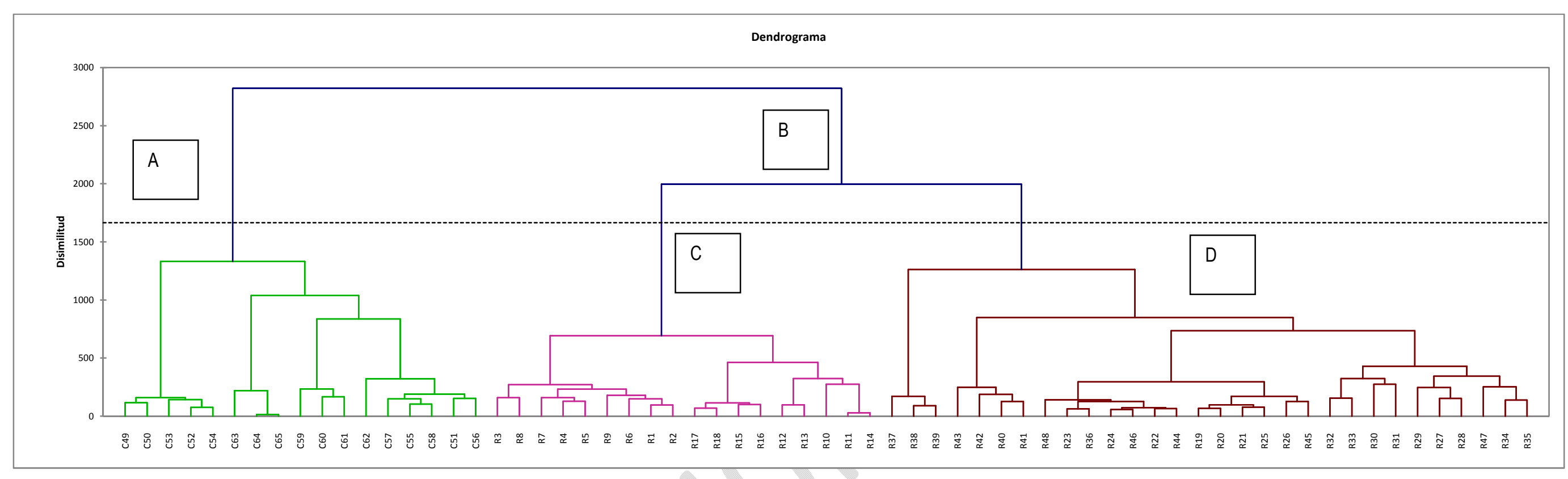

Fig. 7. Cluster analysis. Diversity of forest types 


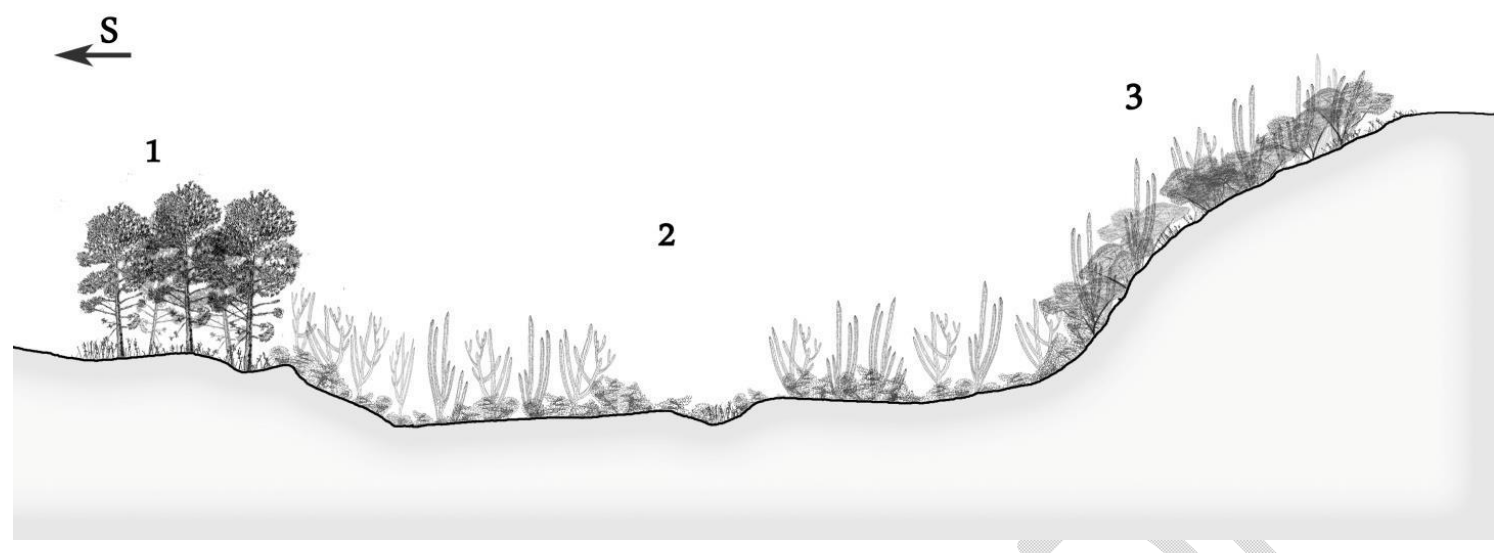

Fig. 8 . Profile of the vegetation of the dry forest of Cibao valley. 1.- Leptogono buchii-Pinetum occidentalis. 2.- Harrisio nashii-Prosopidetum juliflorae 3.- Crotono poitaei-Erythroxyletum rotundifolii
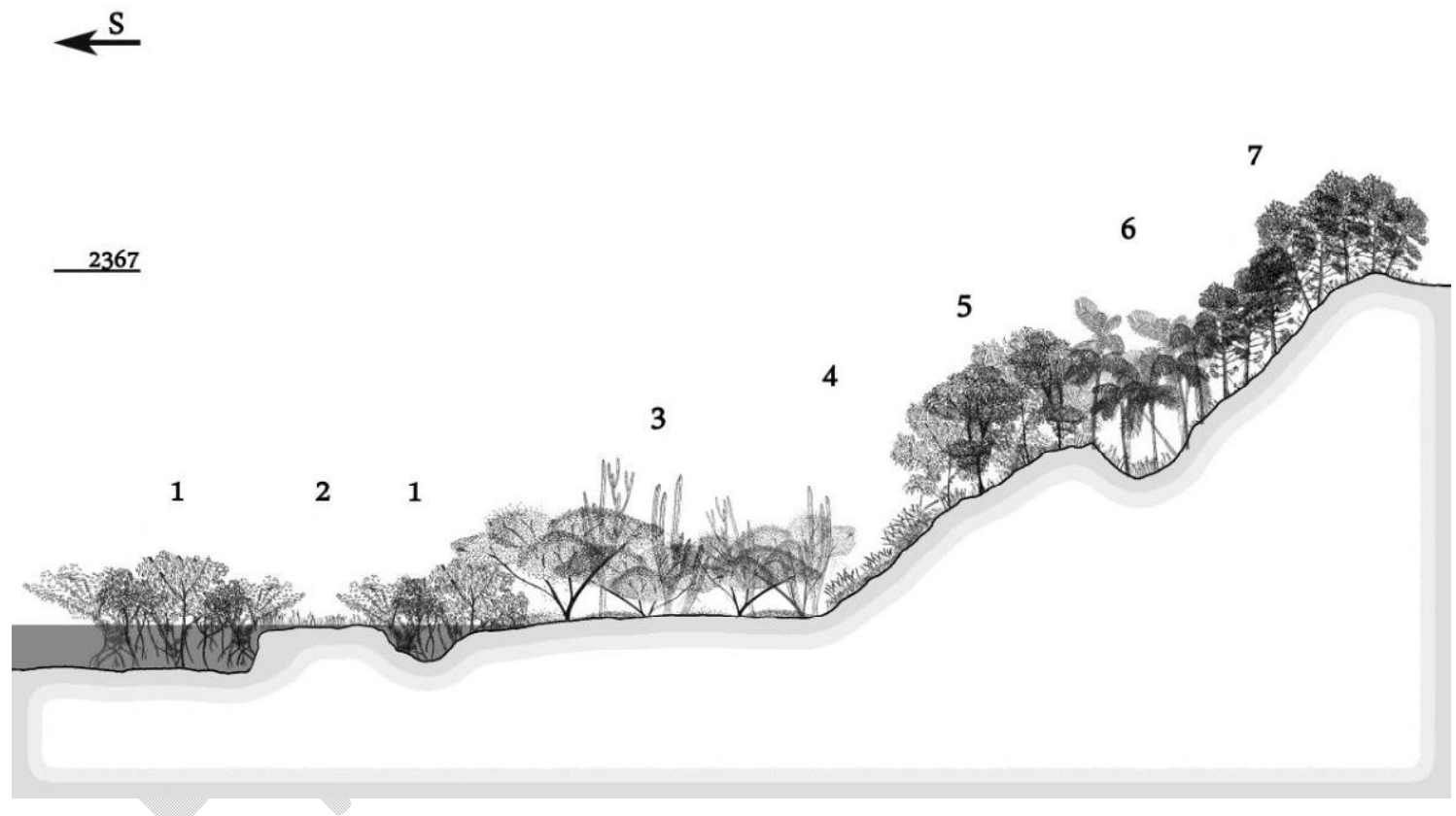

Fig. 9. Profile of the vegetation of the dry forest of Azua-Bani. Broad-leaved forest. 2.Neoabbottio paniculatae-Guaiacetum officinali. 3.- Solano microphylli-Leptochloopsietum virgatae

This group includes dry forest communities between Pedernales and Barahona. The territory has a semiarid infratropical thermotype and reef limestone substrates. This forest is rich in coarse and spiny plants: Cylindropuntia caribaea (Britt. \& Rose) Kunth, Cameraria linearifolia Urb., Bursera simaruba (L.) Sarg. and Agave antillarum Descourt.; and has 24 endemics, including particularly Melocactus pedernalensis
M. Mejía \& R. García, Malpigina micropetala Urb., Thouinia domingensis Urb. \& Radlk., Thouinidium inaequilaterum Alain and Lonchocarpus pycnophyllus Urb. These samples are clearly separated from the rest due to the fact they constitute specific endemic habitats.

These forests are crucial to maintaining the biodiversity of this island -considered a 
biodiversity hotspot [24], and also for preserving the relation between forest stands and the water cycle, which is of such overriding importance to society [25-27]. The state of transition between the cloud, dry and transitional forest is affected by various factors: agriculture, desforestation to obtain charcoal, in which a case in point is the mangrove. Another factor is the considerable increase in invasive species favoured by tourism and by the dispersion of fruits and seeds by birds [28,29]; a particular case is Eichhornia crassipes (Mart.) Solms which is very abundant in the mangrove swamps of Laguncularia racemosa (L.) Gaertn. in the Dominican Republic [30]. Another case of invasive species on the island is Lonicera japonica Thunb., a native of China which is invasive in the southern United States [31]; it was introduced in the Dominican Republic as an ornamental plant, and has now spread beyond cultivated areas -particularly in the mountains- due to a possible confusion with Lonicera confusa DC. This affects forest conservation. The same occurs with Lonicera caprifolium L., a native of Europe which has a tendency to spread beyond its cultivated areas and become naturalised. Opportunists invasive non-native species, modify the native alpha and beta diversity; with which compete for water and nutrients. It seems correct to say that the diversity of native species is reduced. However [32] concluded that non-native species diversity improve, which seems correct since most communities obtained in the degradation of ecosystems are transitional, but this affects the stability of indigenous communities in the time scale and space.

\section{CONCLUSION}

There are areas with high dry forest plant cover in the Dominican Republic; these are located in the southwest of the island, specifically in Procurrente de Barahona, Azua-Valle de San Juan-Hoya Enriquillo and in its prolongation towards western Haiti, including Beata Island; and the Cibao Valley-Montecristi. These territories have a high rate of endemics, and as a result the habitats in which they are found should also be considered endemic. The cloud forest, however, is always located in the mountains as a consequence of the moisture-laden winds from the Atlantic. In both cases the distribution of the forest responds to the environmental factors on the island, which has a high rate of endemics owing to the island phenomenon, making it a hotspot in the Caribbean.

\section{ACKNOWLEDGMENTS}

Ms Pru Brooke Turner (MA Cantab.) for the English translation of this article, and the architect Francisco Javier Quiros Higueras by developing profiles of vegetation.

\section{COMPETING INTERESTS}

Authors have declared that no competing interests exist.

\section{REFERENCES}

1. Noguchi S, Nik AR, Yusop Z, Tani M, Sammori T. Rainfal-runoff responses and roles of soil moisture variations to the response in tropical rain forest, Bukit Tarek, Peninsular Malaysia. J. For. Res. 1997;2:125-132.

2. $\mathrm{Xu} X$, Hirata E, Tokashiki Y, Shinohara T. Structure and Species diversity on subtropical evergreen broad-leaved forest in Northern Okinawa Island, Japan. J. For. Res. 2001;6:203-210.

3. Cheng $S$, Hiwatashi $Y$, Imai $H$, Naito $M$, Numata, T. Deforestation and degradation of natural resources in Ethiopia: Forest management implications from a case study in the Belete-Gera Forest. J. For. Res. 1998;3:199-204.

4. Xiang W, Liu S, Lei X, Frank SC, Tian D, Wang G, Deng $X$. Secondary florest floristic composition, structure, and spatial pattern in subtropical China. J. For. Res. 2013;18(1):111-120.

DOI: $10.1007 / \mathrm{s} 10310.011 .0329 .7$.

5. Zobel DB, Ram J, Bargali SS. Structural and physiological changes in Quercus leucotrchophora and Pinus roxburghii associated with stand disturbance in the Kumaun Himalaya, India. International J. Ecology and Environmental Sciences. 1995;21:45-66.

6. Shahi C, Sharma A, Bargali K, Bargali K, Bargali SS. Effect of disturbance gradient on forest floor biomass in natural forest ecosystems in and around Nainital. The Ecoscan. 2014;8(1\&2):163-168.

7. Pande R, Bargali K, Pande N. Impacts of disturbance on the population structure and regeneration status of tree species in a Central Himalayan Mixed-Oak Forest, India. Taiwan Journal of Forest Science. 2014;29(3):179-192. 
8. Kittur B, Swamy SL, Bargali SS, Jhariya MK. Wildland fires and moist deciduous forests of Chhattisgarh, India: Divergent component assessment. Journal of Forestry Research. 2014;25(4):857-866.

9. Tripathi BC, Rikhari HC, Bargali SS, Rawat YS. Species composition and regeneration in disturbed forest sites in the oak zone in and around Nainital. Proceedings of Indian National Science Academy. 1991;57(B): 381-390.

10. Lavoie M, Mack MC, Hiers JK, Pokswinski $\mathrm{S}$. The effect of restoration treatments on the spatial variability of soil processes under longleaf pine trees. Forests. 2012; 3:591-604.

DOI: 10.3390/f3030591.

11. Oliveras I, Malhi Y, Salinas M, Huaman V, Urquiaga-Flores E, Kala-Mamani J, Quintano-Loaiza JA, Cuba-Torres I, Lizarraga-Morales N, Román-Cuesta RM. Changes in forest structura and composition after fire in tropical montane cloud forests near the Andean treeline. Plant Ecology \& Diversity. 2014; 7(1-2):329-340.

Available:http://dx.doi.org/10.1080/175508 74.2013.816800

12. Saito S. Effects of Severe typhoon on forest dynamics in a Warn-temperature evergreen broad-leaved forest in South western Japan. J. For Res. 2002;7:137143.

13. Román-Dañobeytia FJ, Levy-Tacher SI, Macario-Mendoza $\mathrm{P}$, Zúñiga-Morales $\mathrm{J}$. Redefining secondary forests in the mexican forest code: Implications for management, restoration and conservation. Forests. 2014;5:978-991.

DOI: $10.3390 / f 5050978$.

14. Keenan RJ. Adaptation of forests and forest management to climate change: An editorial. Forests. 2012;3:75-82.

DOI: 10.3390/f3010075.

15. Balderas Torres A, Ontiveros Enriquez R, Skutsch M, Lovett JC. Potential for climate change mitigation in degraded forests: A study from La primavera, Mexico. Forests. 2013;4:1032-1054.

DOI: 10.3390/f4041032.

16. McGinley K, Alvarado R, Cubbage F, Diaz D, Donoso PJ, Gonçalvez Jacovine LA, de Silva FL, Mclntyre C, Monges Zalazar E. Regulating the sustainability of forest management in the Americas: Crosscountry comparisons of forest legislation. Forests. 2012;3:467-505.
DOI: $10.3390 /$ f3030467.

17. Van der Maarel E. Transformation of cover-abundance values in phytosociology and its effects on community similarity. Vegetatio. 1979;39:97-114.

18. Cano E, Cano-Ortiz A, del Río S, Alatorre $\mathrm{J}$, Veloz A. Bioclimatic map of the Dominican Republic. Plant Sociology. 2012b;49:81-90.

DOI: 107338/pls2012491/04.

19. Cano E, Cano-Ortiz A. Establishment of biogeographic areas by distributing endemic flora and habitats (Dominican Republic, Haiti R.). In Global Advances in Biogeography. Ed. Lawrence Stevens INTECH, Croatia. 2012;99-118.

20. Wei $Y$, Ouyang Z, Miao H, Zheng H. Exotic Pinus caribaea causes soil quality to deteriórate on former abandoned land compared to an indigenous Podocarpus plantation in the tropical forest area of southern China. J. For. Res. 2009;14:221228.

DOI: $10.1007 / \mathrm{s} 10310.009 .0130 . z$.

21. Cano E, Veloz A, Cano-Ortiz A. Rain forests in subtropical mountains of Dominican Republic. American Journal of Plant Sciences. 2014;5:1459-1466. Available:http://dx.doi.org/10.4236/ajps.20 14.51016

22. Cano E, Veloz A. Contribution to the knowledge of the plant communities of the Caribbean-Cibensean Sector in the Dominican Republic. Acta Botanica Gallica. 2012;159(2):201-2010.

Available:http://dx.doi.org/10.1080/125380 78.2012.696933

23. Cano-Ortiz A, Musarella CM, Piñar JC, Veloz A, Cano $E$. The dry forest in the Dominican Republic. Plant Biosystems; 2015 (in press).

24. Maunder M, Leiva A, Santiago-Valentín E, Stevenson DW, Acevedo-Rodríguez $\mathrm{P}$, Meerow AW, Mejía M, Clubbe C, Francisco-Ortega J. Plant Conservation in the Caribbean Island Biodiversity Hotspot. Bot Rev. 2008;74:197-207.

25. Kaimowitz D. Forest and water: a polycy perspective. J. For. Res. 2004;9:289-291.

26. Kreye MM, Adams DC, Escobedo FJ. The value of forest conservation for water quality protection. Forests. 2014;5:862884.

DOI: $10.3390 /$ f5050862.

27. Uzawa H. Forest and social common capital. J. For. Res. 2004;9:283-288. DOI: $10.1007 / \mathrm{s} 10310.004 .0107 . x$ 
28. Jurskis V. Plant invasions: Symptoms and contributors rather than causes of environmental dedradation. Forests. 2012; 3:896-902.

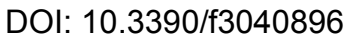

29. Gardener MP, Bustamante RO, Herrera I, Durigan G, Pivello VR, Moro MF, Stoll A, Langdon B, Barruch Z, Rico A, ArredondoNuñez $A$, Flores $S$. Plant invasions research in Latin America: fast track to a more focused agenda. Plant Ecology \& Diversity. 2012;5(2):225-232.

30. Cano E, Cano-Ortiz A, Veloz A, Alatorre J, Otero R. Comparative analysis between the mangrove swamps of the Caribbean and those of the State of Guerrero (Mexico). Plant Biosystems 2012a; 146(supplement):112-130.

Available:http://dx.doi.org/10.1080/112635 04.2012 .704885

31. Wang $\mathrm{HH}$, Wonkka CL, Grant WE, Rogers W. Potential range expansión of Japanese Honeysuckle (Lonicera japônica Thunb.) in southern U.S. forestlands. Forests. 2012; 3:573-590.

DOI: $10.3390 /$ f3030573.

32. Fukami T, Bellingham PJ, Peltzer DA, Walker LR. Non-native plants disrupt dual promotion of native alpha and beta diversity. Folia Geobot. 2013;48:319-333.

(c) 2015 Cano-Ortiz et al.; This is an Open Access article distributed under the terms of the Creative Commons Attribution License (http://creativecommons.org/licenses/by/4.0), which permits unrestricted use, distribution, and reproduction in any medium, provided the original work is properly cited.

Peer-review history:

The peer review history for this paper can be accessed here: http://www.sciencedomain.org/review-history.php?iid=1138\&id=5\&aid=9280 